\title{
Assessing Competitiveness of Fine Fescues (Festuca L. spp.) and Tall Fescue (Schedonorus arundinaceous (Schreb.) Dumort) Established with White Clover (Trifolium repens L., WC), Daisy (Bellis perennis L.) and Yarrow (Achillea millefolium L.)
}

\author{
Daniel Hahn ${ }^{1}$, Alejandro Morales ${ }^{1}$, Ciro Velasco-Cruz ${ }^{2}$ and Bernd Leinauer ${ }^{1,2, *}$ \\ 1 Centre for Crop Systems Analysis, Department of Plant Sciences, Wageningen University and Research, \\ Droevendaalsesteeg 1, 6708PB Wageningen, The Netherlands; Daniel.hahn@wur.nl (D.H.); \\ Alejandro.MoralesSierra@wur.nl (A.M.) \\ 2 Department of Extension Plant Science, New Mexico State University, Las Cruces, NM 88003, USA; \\ cvelasco@nmsu.edu \\ * Correspondence: Bernd.Leinauer@wur.nl or Leinauer@nmsu.edu; Tel.: +1-575-646-2546
}

Citation: Hahn, D.; Morales, A.; Velasco-Cruz, C.; Leinauer, B. Assessing Competitiveness of Fine Fescues (Festuca L. spp.) and Tall Fescue (Schedonorus arundinaceous (Schreb.) Dumort) Established with White Clover (Trifolium repens L., WC), Daisy (Bellis perennis L.) and Yarrow (Achillea millefolium L.). Agronomy 2021, 11, 2226. https:// doi.org/10.3390/agronomy11112226

Academic Editor: Aritz Royo-Esnal

Received: 29 July 2021

Accepted: 31 October 2021

Published: 3 November 2021

Publisher's Note: MDPI stays neutral with regard to jurisdictional claims in published maps and institutional affiliations.

Copyright: (c) 2021 by the authors. Licensee MDPI, Basel, Switzerland. This article is an open access article distributed under the terms and conditions of the Creative Commons Attribution (CC BY) license (https:// creativecommons.org/licenses/by/ $4.0 /)$.
Abstract: Regulatory restrictions on herbicide use for managing turfgrass weeds has prompted the search for alternative control strategies. Fescue (Festuca) species were identified for their potential to interfere with growth of annual and perennial weeds. In a study conducted in 2018 and 2019, six fescue cultivars were tested from five different species for interference with the growth of three common turfgrass weeds: white clover (Trifolium repens L., WC), daisy (Bellis perennis L.) and yarrow (Achillea millefolium L.). Fine (Festuca L. spp.) and tall fescues (Schedonorus arundinaceus (Schreb.) Dumort.) were sown and grown in a field trial for 14 days before overseeding with different weeds. vigor and visual quality of grasses, weed cover, and vegetation cover was recorded regularly for 84 days. Differences in mean temperatures and precipitation between the two years of the study resulted in differences in growth of grasses and weeds, as well as in the extent of weed interference of fescue cultivars. Cultivars Musica (F. rubra L. ssp. commutata Gaudin) and Barpearl (F. rubra L. ssp. littoralis) were least affected by weed growth during both years, but there was overlap with other cultivars for the measured parameters. Melyane (tall fescue) was deemed unsuitable for natural weed suppression because growth and vigor declined after first mowing, ultimately leading to unacceptable visual quality. Turfgrass visual scores were moderately negatively correlated to weed cover in both years. Future research should focus on F. rubra L. ssp. rubra Gaudin and F. rubra L. ssp. littoralis subspecies and identify the mechanisms used to interfere with weed growth.

Keywords: broadleaf weeds; growth interference; turfgrass vigor; visual quality; weed cover; vegetation cover

\section{Introduction}

In some European countries, concerns over pesticide misuse have led to strict regulations, particularly in regards to herbicides used on amenity areas [1]. In Denmark, metabolites of pesticides were detected in $40 \%$ of groundwater wells that supply drinking water to communities [2]. In the Netherlands, where $40 \%$ of all drinking water is derived from surface water, problems with pesticide contamination led to voluntary agreements with municipalities to reduce herbicidal use in amenity areas [1]. Such voluntary agreements are also in place for athletic fields, as exemplified by the 'Green Deal' in The Netherlands [3]. The 'Green Deal' was initiated to restrict the use of pesticides on amenity areas entirely; however an exemption period was granted until 2022 which allows the use of selected pesticides under strict conditions [3]. In turf settings, herbicides are the most used pesticide in terms of product use [4]. Herbicides are mainly applied to control 
broadleaf dicotyledonous weeds, such as white clover (Trifolium repens L., WC) or dandelion (Taraxacum officinale L.), which are the most problematic weeds in athletic fields [5]. In these areas, the main objective is to maintain a mono stand of turfgrass species that produce aesthetically pleasing surfaces with a certain standard of playing quality [6,7].

Weeds in athletic fields or golf course fairways can be defined as unwanted species that interfere with the visual appearance and playing quality of these surfaces [7]. Weeds often establish in sparse areas as a result of abiotic/biotic stress or management failures such as improper water management or fertilization $[8,9]$. Once established, weeds compete with desirable turfgrass species for resources (namely water), light and nutrients, as well as space, such as in below ground root competition [6].

The requirement for desirable turfgrass species has shifted towards low-input species to reduce the ecological footprint of amenity turfgrass areas $[10,11]$. Consequently, an ecological approach to weed management should focus on establishing sustainable turfgrass species that require low inputs of valuable resources such as water and fertilizer, while providing a dense, healthy turf canopy that competes well against weeds $[6,9,12,13]$.

Fine fescues (Festuca L. spp.) can establish a dense turf canopy with minimal inputs of water, fertilizer and pesticides [12]. These perennial fine-leaved turf species thrive in dry conditions but are also adapted to shade and low $\mathrm{pH}$ growing conditions [12]. Fine fescues can be grouped into two complexes, the red fescues (Festuca rubra L.) and the sheep fescues (Festuca ovina L.) [10,14]. Within the red fescue species, strong creeping red fescue (F. rubra L. ssp. rubra Gaudin) and slender creeping red fescues (F. rubra L. ssp. littoralis (G. Mey.) Auquier) produce rhizomes [14], while Chewings fescue (F. rubra L. ssp. commutata Gaudin) exhibits a bunch type growth. Chewings fescue was identified as a species that provides acceptable quality on golf fairways under low- nitrogen inputs, defined as $4.9 \mathrm{~g}$ of nitrogen per square meter, and is a superior species under reduced irrigation and low pesticide inputs compared to other fine fescue species and colonial bentgrass (Agrostis capillaries L., CL) mixtures [15].

Hard fescue (F. brevipila Tracey) belongs to the sheep fescue complex, establishes slowly, and has a bunch type rooting system [16]. Hard fescue has slower establishment vigor compared to creeping red fescue and Chewings fescue, and demonstrated less natural weed suppression capacity $[10,17]$.

Tall fescue (Schedonorus arundinaceus (Schreb.) Dumort.), is a stand-alone fescue complex, establishes quickly from seed [16] and can be easily separated from other turf species because of the wide leaf width of 4-18 mm. In comparison, Festuca rubra species have leaf widths of less than $2 \mathrm{~mm}$ [10]. Additionally, tall fescues have a deep rooting system, making them one of the most drought resistant cool-season turfgrass species [18]. Drought resistance combined with wear tolerance makes tall fescue one of the most used grass species for athletic fields in European transition zones [19].

Apart from being a sustainable turfgrass species, fine fescues and tall fescue have also demonstrated allelopathic potential [17,20-22]. Fine fescues and tall fescue produce compounds which interfere with the growth of some neighboring plants, imparting them with natural weed suppression capabilities [20,22]. A series of field studies of 78 fine-leaf fescue cultivars showed that three Chewings fescue cultivars and one hard fescue cultivar showed 'good' natural weed suppression capabilities (defined as more than $70 \%$ of weeds suppressed compared to a control) [17].

Information is lacking on the prevalence of weed suppression capabilities among certain fescue complexes or species. Moreover, it is unknown if fine fescues and tall fescues interfere differently with the growth of different weed species. In this study, we investigated the extent of growth interference of white clover (Trifolium repens L., WC), daisy (Bellis perennis L.) and yarrow (Achillea millefolium L.), three common European broadleaf weeds, during the establishment phase of six fescue cultivars from five species. One tall fescue variety was added to the study to explore if a more rapidly developing grass species, such as Schedonorus arundinaceus (Schreb.) Dumort., outcompetes neighboring weed species differently than fine fescues. It was also investigated if final grass vigor was negatively 
correlated to weed establishment, if better visual scores could be attributed to low weed cover or high vigor and, lastly, if quantitative vegetation cover estimates gave results that were similar to visual vigor scores.

\section{Materials and Methods}

\subsection{Field Site and Cultivars Selected}

The field trials were conducted at the Barenbrug Turfgrass Research Station in Wolfheze, The Netherlands $\left(52^{\circ} 00^{\prime} \mathrm{N}, 5^{\circ} 47^{\prime} \mathrm{E}\right)$. The first field trial was sown on 13 July 2018 , and the replication of the experiment was sown 22 August 2019, on an adjacent field. Both experiments were conducted for 84 days each. Soil in the upper $15 \mathrm{~cm}$ was loamy sand (79\% sand, $12 \%$ silt, 3\% clay) with a $\mathrm{pH}$ of five and an organic matter content of $6 \%$. Each plot measured $1.5 \mathrm{~m} \times 1.5 \mathrm{~m}$. On the first day of each field trial, 30 plots out of 34 were sown with an equal number of seeds $\left(20,150\right.$ per $\left.\mathrm{m}^{-2}\right)$ of the following fine and tall fescue cultivars: Musica (Chewings fescue), Mentor (hard fescue), Samanta and Barpearl (slender creeping red fescue), Barisse (strong creeping red fescue), and Melyane (tall fescue). The remaining four plots were left blank for later introduced weed controls. It was originally planned to include varieties that were also investigated by Bertin et al. [17]. The authors of this study observed the visual weed suppression ability of fine fescues in Ithaca, NY from 1998 to 2002. Unfortunately, none of these cultivars are commercially available in Europe. Therefore, first cultivars from the British Society of Plant Breeders list were selected [23] and second from a companion study which was conducted concurrently in a growth chamber. First results indicated promising growth interference potential for the selected species and cultivars included in this study. Sowing rates were based on guidelines published by Beard [24] (Table 1).

Table 1. Sowing rates $\left(\mathrm{g} \mathrm{m}^{-2}\right.$ ) and number of seeds (seeds $\mathrm{m}^{-2}$ ) of fine (Festuca L. spp.), tall fescue (Schedonorus arundinaceus (Schreb.) Dumort.) cultivars, and weed species used in the study.

\begin{tabular}{cccc}
\hline Cultivar & Species & Common Name & $\mathbf{g ~ m}^{-\mathbf{2}}$ \\
\hline Mentor & F. brevipila & Hard & 21.8 \\
Musica & F. rubra commutata & Chewings & 17.3 \\
Barpearl & F. rubra littoralis & Slender creeping & 22.9 \\
Samanta & F. rubra littoralis & Slender creeping & 19.5 \\
Barisse & F. rubra rubra & Strong creeping & 28.2 \\
Melyane & Schedonorus arundinaceus & Tall & 47.8 \\
\hline- & Achillea. millefolium L. & Yarrow & 0.9 \\
- & Bellis perennis L. & Daisy & 1.0 \\
\hline
\end{tabular}

The seedbed was prepared by harrowing, removing stones by hand, raking and rolling. Before sowing, the soil was loosened again through raking. Subsequently, plots were seeded by evenly spreading seed by hand in two directions perpendicular to one another. After depositing the seeds, the seedbed was carefully raked to cover the seeds with soil, and then irrigated. The plots were then covered with a thin fleece to retain moisture in the soil and to promote seed germination.

Fourteen days after seeding of the grasses (DAS), all plots except grass controls were oversown with one of three weed species, namely clover, daisy, and yarrow, or with a mixture of all three species that included each weed at one-third of the full rate (hereafter referred to as 'weed treatments'). Four plots were initially not seeded with grasses and only received weed seeds at 14 DAS (weed controls). Weed seeding rates are listed in Table 1 . The 14 day delay in seeding of the weeds was chosen to allow time for allelopathic chemicals produced by donor plants (grasses) to be released into the soil medium and potentially have a growth inhibitory effect on receiver plants (weeds) [20,21,25].

Twenty-one days after seeding of the grasses (DAS), the area was mowed at a height of $20 \mathrm{~mm}$, using a Jacobson TR3 reel mower (TR3, Jacobson, Racine, WI, USA) without 
box attachments to return clippings. Subsequently mowing was applied twice per week at $15 \mathrm{~mm}$. Mowing height was selected to represent a height commonly found on golf course fairways, which was also shown to be acceptable for tall fescue [26].

At 28 DAS, 42 DAS, 56 DAS, and 70 DAS, granular fertilizer (NPK 12-10-18 Arm, Eurosolids, Westmaas, The Netherlands) was applied at a rate of $200 \mathrm{~kg} \mathrm{ha}^{-1}$ year ${ }^{-1}$, which amounted to $2.4 \mathrm{~g} \mathrm{~m}^{-2}$ year $^{-1}$ of nitrogen.

\subsection{Data Collection}

Digital image analysis was used to determine percent green vegetation cover, which includes both grasses and weeds cover of each plot (referred to as vegetation cover) $[27,28]$ at the end of the research period (84 DAS). A picture covering an area of 0.9 by $1.1 \mathrm{~m}$ was taken of the center of each plot with a Canon PowerShot SX 200 (Canon Inc., Tokyo, Japan) set at ISO 200, Aperture 2.6 and shutter speed $1 / 60 \mathrm{~s}$. The camera had a distance to the ground of $60 \mathrm{~cm}$ and was housed in an enclosed box fitted with four halogen light bulbs designed to provide uniform light coverage [29]. The images were subsequently processed with the software Turf Analyzer [30], which applies a green pixel recognition algorithm to calculate the percentage of vegetation cover.

Plots were also rated for visual quality on a scale of one to nine [31,32] on 84 DAS. Visual quality is a score that includes density, color, homogeneity, and uniformity, with one representing a poorly established sward with many weed species being present and nine representing a dense canopy with a monostand of sown turfgrass species free of weeds $[32,33]$.

Scores for turfgrass vigor were collected on 14,39 , and 84 DAS and weed cover were recorded on 26, 54 and 84 DAS. Vigor was recorded visually from zero to nine [33] with zero denoting no grasses, one representing a turf sward that just germinated and nine indicating a perfectly established, dense sward. Seedling vigor or establishment can be defined as the speed at which a plant develops from germination into a mature plant, and combines groundcover scores and plant height over time [33,34]. Thus, vigor can be described as a combined score of germination speed, development of biomass and turf cover [33]. Therefore, a plant that shows higher vigor compared to another will develop more rapidly into a mature plant [35]. On the first two sampling dates, turfgrass scores and weed cover measurements were not collected on the same day because initial seeding of grasses and weeds was staggered. Plots were first seeded with grass, then overseeded with weeds two weeks later. Thus, the first weed cover data were collected 12 days after first turfgrass vigor scores (26 DAS vs. 14 DAS) to allow weeds to grow sufficiently to accurately estimate weed cover. The second set of turfgrass vigor data were collected 35 days after the first set, and the second set of weed coverage data were collected 32 days after the first set. The third and last set of data all were collected on the same day, 84 DAS. The number of weeds were determined by line intersect analysis (LIA) placing a $1 \mathrm{~m} \times 1 \mathrm{~m}$ frame with 100 intersections, each $10 \mathrm{~cm}$ apart, on each plot and counting the presence or absence of weed species under each intersection. Presence of a weed species under an intersection was recorded as ' $1 \%$ ' weed cover $[31,36]$.

\subsection{Environmental Conditions}

During the 2018 experiment, air temperatures averaged $17.8{ }^{\circ} \mathrm{C}$ and rainfall was recorded on 24 days (total rainfall $205 \mathrm{~mm}$ ). In 2019 , temperatures averaged $12.9^{\circ} \mathrm{C}$, and rainfall was recorded on 50 days (total rainfall $322 \mathrm{~mm}$ ) (see Table 2). Weather data were recorded by a weather station, which was located onsite. 
Table 2. Monthly average air temperatures $\left({ }^{\circ} \mathrm{C}\right)$ and precipitation $(\mathrm{mm})$ at Barenbrug research station, Wolfheze, The Netherlands.

\begin{tabular}{ccccccccc}
\hline \multirow{2}{*}{ Climate Parameters } & \multicolumn{4}{c}{2018} & \multicolumn{5}{c}{2019} \\
\cline { 2 - 9 } & Jul. & Aug. & Sept. & Oct. & Aug. & Sept. & Oct. & Nov. \\
\hline Air temperature $\left({ }^{\circ} \mathrm{C}\right)$ & & & & & & & & \\
Minimum & 13.7 & 12.3 & 8.7 & 6.0 & 12.6 & 9.4 & 7.6 & 3.7 \\
Maximum & 31.6 & 26.0 & 21.7 & 16.8 & 30.8 & 20.5 & 15.5 & 10.8 \\
Average & 22.7 & 18.8 & 14.7 & 10.8 & 20.8 & 14.3 & 11.4 & 7.1 \\
\hline $\begin{array}{c}\text { Precipitation }(\mathrm{mm}) \\
\text { Average }\end{array}$ & 0.3 & 4.2 & 2.2 & 0.8 & 1.9 & 3.6 & 4.2 & 5.1 \\
\hline
\end{tabular}

\subsection{Statistical Analysis}

The general experimental layout of the plots was an Extended Factorial Design which consisted of two treatment factors, one with seven grasses and another with five weeds. This type of designs are also known as Augmented Factorial [37]. Plots were arranged as a randomized complete block $(\mathrm{RCB})$ with each treatment replicated four times. The treatment design was incomplete because it did not include a grass control $\times$ weed control plot. Therefore, we combined both treatment factors (grass and weeds) to one treatment factor with 34 levels, as in Marini [38], and applied a pairwise comparison to determine significant differences between the treatment combinations. Calculations of weed cover are based on counts and data were analyzed using a Negative Binomial distribution. Vigor and quality data were analyzed based on a normal distribution. Since vigor was only recorded for grass species, data of plots sown with weeds only (i.e., weed controls) were removed from the vigor analysis. Initial statistical analyses revealed a significant DAS main effect, and DAS was also observed in each relevant interaction term that was shown to be significant. Consequently, ANOVA was used to analyze weed cover and vigor separately for each DAS. Weed cover, grass vigor, and visual quality data were analyzed using PROC GLIMMIX in SAS statistical software version 9.4 (SAS Institute, Cary, NC, USA). The level of significance was set equal to $5 \%$. The SIMULATE method was selected to control for multiplicity and compute adjusted $p$-values for multiple comparisons. To explore the relationship between visual quality and grass vigor and weed cover, and between vegetation cover and grass vigor and weed cover, Pearson's correlations among these output values collected 84 DAS were computed and coefficient of determination values (r) were reported.

\section{Results}

Analysis of variances of all measured parameters revealed significant main effects and significant interaction effects at all sampling dates (Table 1).

\subsection{Grass Vigor}

In 2018, vigor scores 14 DAS ranged from 1.0 (Samanta in combination with all four tested weeds and Musica in combination with daisy and yarrow) to 2.8 for Mentor in combination with clover. Mentor was consistently among the cultivars that rated highest for vigor (Table 3). Results were different in 2019, when Melyane consistently placed in the group with the highest vigor ratings, indicating an early, fast establishment when compared to other cultivars (Table 3). On DAS 39 in 2018, vigor scores again ranged from 1.0 (cultivar Samanta in weed control plots) to 3.5 for Mentor in combination with clover and Melyane in combination with daisy (Table 3). Vigor scores in 2019, 39 DAS only differed between Musica with yarrow and Melyane with clover, for which ratings of 5.5 and 3.9, respectively, were recorded (Table 4). In 2018, vigor differences among cultivars were no longer discernable at the end of the research period on DAS 84 (Table 3). Although at 84 DAS, in 2019, Barpearl and Musica placed in the group with the highest vigor scores for 
all weed treatments, there was extensive overlap with other cultivars and no clear trends emerged (Table 4).

Table 3. $p$-Values from ANOVA to test the effects of treatments (grasses seeded with different weed species) and sampling year (Year), and their interactions on grass vigor, weed cover, and grass quality at three sampling days (DAS).

\begin{tabular}{cccccccc}
\hline \multirow{2}{*}{ Effect } & \multicolumn{3}{c}{ Vigor } & & & Weed Cover & \multicolumn{2}{c}{ Quality } \\
\cline { 2 - 7 } & DAS 14 & DAS 39 & DAS 84 & DAS 26 & DAS 54 & DAS 84 & DAS 84 \\
\hline Treatment & $<0.0001$ & 0.0023 & $<0.0001$ & $<0.0001$ & $<0.0001$ & $<0.0001$ & $<0.0001$ \\
Year & 0.0024 & $<0.0001$ & $<0.0001$ & $<0.0001$ & 0.0214 & $<0.0001$ & 0.0053 \\
Treatment & $<0.0001$ & $<0.0001$ & $<0.0001$ & 0.0083 & $<0.0001$ & $<0.0001$ & $<0.0001$ \\
$\quad$ Year & & & & & & & \\
\hline
\end{tabular}

Table 4. Grass vigor scores of six fine (Festuca L. spp.) and tall fescue (Schedonorus arundinaceus (Schreb.) Dumort.) cultivars sown in 2018 and 2019 14, 39, 84 days after seeding (DAS) with white clover (Trifolium repens L.), daisy (Bellis perennis L.), yarrow (Achillea millefolium L.), a mixture of all three weed species or without weeds (Control). Grass vigor describes a combined score of germination speed, development of biomass and turf cover, and ranges from 0 to 9 with $0=$ no germination and 9 = fully established, dense turf sward.

\begin{tabular}{|c|c|c|c|c|c|c|c|c|}
\hline \multirow{2}{*}{ Weed } & \multirow{2}{*}{ Species } & \multirow{2}{*}{ Cultivar } & \multicolumn{2}{|c|}{ DAS 14} & \multicolumn{2}{|c|}{ DAS 39} & \multicolumn{2}{|c|}{ DAS 84} \\
\hline & & & 2018 & 2019 & 2018 & 2019 & 2018 & 2019 \\
\hline \multirow[t]{6}{*}{ Clover } & F. rubrar. & Barisse & $1.5 \mathrm{ABC} *$ & $1.3 \mathrm{E}$ & $3.0 \mathrm{ABC}$ & $4.4 \mathrm{AB}$ & $6.9 \mathrm{~A}$ & 5.9ABCDE \\
\hline & F. rubra l. & Barpearl & $1.5 \mathrm{ABC}$ & $1.6 \mathrm{E}$ & 1.9BCDE & $4.9 \mathrm{AB}$ & $7.0 \mathrm{~A}$ & $6.5 \mathrm{AB}$ \\
\hline & Schedon. $a$. & Melyane & $1.8 \mathrm{ABC}$ & $3.3 \mathrm{AB}$ & 2.8ABCD & $3.9 \mathrm{~B}$ & $6.6 \mathrm{~A}$ & 4.5DE \\
\hline & F. brev. & Mentor & $2.8 \mathrm{~A}$ & $1.3 \mathrm{E}$ & $3.5 \mathrm{~A}$ & $4.0 \mathrm{AB}$ & $6.9 \mathrm{~A}$ & 5.5ABCDE \\
\hline & F. rubrac. & Musica & $1.3 \mathrm{BC}$ & 2.0BCDE & 2.6ABCD & $5.3 \mathrm{AB}$ & $7.0 \mathrm{~A}$ & 6.0ABCD \\
\hline & F. rubra l. & Samanta & $1.0 \mathrm{C}$ & $1.3 \mathrm{E}$ & 1.4DE & $4.4 \mathrm{AB}$ & $6.8 \mathrm{~A}$ & $6.3 \mathrm{ABC}$ \\
\hline \multirow[t]{6}{*}{ Daisy } & F. rubrar. & Barisse & $1.8 \mathrm{ABC}$ & $1.4 \mathrm{E}$ & $2.8 \mathrm{ABCD}$ & $4.6 \mathrm{AB}$ & $6.6 \mathrm{~A}$ & 5.8ABCDE \\
\hline & F. rubra l. & Barpearl & $1.5 \mathrm{ABC}$ & $1.4 \mathrm{E}$ & 2.4ABCDE & $4.5 \mathrm{AB}$ & $6.8 \mathrm{~A}$ & $6.6 \mathrm{~A}$ \\
\hline & Schedon. a. & Melyane & $2.5 \mathrm{AB}$ & 3.1ABC & $3.5 \mathrm{~A}$ & $4.0 \mathrm{AB}$ & $6.4 \mathrm{~A}$ & $4.4 \mathrm{E}$ \\
\hline & F. brev. & Mentor & $2.0 \mathrm{ABC}$ & $1.1 \mathrm{E}$ & 2.6ABCD & $4.0 \mathrm{AB}$ & $6.6 \mathrm{~A}$ & 5.5ABCDE \\
\hline & F. rubra c. & Musica & $1.0 \mathrm{C}$ & 2.0BCDE & 1.9BCDE & $5.1 \mathrm{AB}$ & $6.6 \mathrm{~A}$ & $6.8 \mathrm{~A}$ \\
\hline & F. rubral. & Samanta & $1.0 \mathrm{C}$ & $1.5 \mathrm{E}$ & 1.5CDE & $4.4 \mathrm{AB}$ & $7.0 \mathrm{~A}$ & 6.3ABC \\
\hline \multirow[t]{6}{*}{ Yarrow } & F. rubrar. & Barisse & $1.3 \mathrm{BC}$ & $1.1 \mathrm{E}$ & $3.3 \mathrm{AB}$ & $4.5 \mathrm{AB}$ & $6.6 \mathrm{~A}$ & $6.1 \mathrm{ABC}$ \\
\hline & F. rubral. & Barpearl & 1.3BC & $1.8 \mathrm{DE}$ & 2.0ABCDE & $4.8 \mathrm{AB}$ & $7.0 \mathrm{~A}$ & $6.9 \mathrm{~A}$ \\
\hline & Schedon. $a$. & Melyane & $2.0 \mathrm{ABC}$ & $3.4 \mathrm{~A}$ & 2.6ABCD & $4.3 \mathrm{AB}$ & $6.4 \mathrm{~A}$ & 5.0BCDE \\
\hline & F. brev. & Mentor & $2.5 \mathrm{AB}$ & $1.4 \mathrm{E}$ & 3.3AB & $4.0 \mathrm{AB}$ & $7.1 \mathrm{~A}$ & 5.8ABCDE \\
\hline & F. rubrac. & Musica & $1.0 \mathrm{C}$ & 2.1ABCDE & 1.9BCDE & $5.5 \mathrm{~A}$ & $7.0 \mathrm{~A}$ & $6.8 \mathrm{~A}$ \\
\hline & F. rubral. & Samanta & $1.0 \mathrm{C}$ & $1.3 \mathrm{E}$ & $1.4 \mathrm{DE}$ & $4.6 \mathrm{AB}$ & $5.8 \mathrm{~A}$ & $6.1 \mathrm{ABC}$ \\
\hline \multirow[t]{6}{*}{ Mixture } & F. rubrar. & Barisse & $1.8 \mathrm{ABC}$ & $1.4 \mathrm{E}$ & 2.6ABCD & $4.8 \mathrm{AB}$ & $6.8 \mathrm{~A}$ & 6.0ABCD \\
\hline & F. rubra l. & Barpearl & $1.3 \mathrm{BC}$ & $1.4 \mathrm{E}$ & 2.1ABCDE & $5.1 \mathrm{AB}$ & $6.9 \mathrm{~A}$ & $6.3 \mathrm{ABC}$ \\
\hline & Schedon. $a$. & Melyane & $2.5 \mathrm{AB}$ & $3.4 \mathrm{~A}$ & $3.4 \mathrm{AB}$ & $4.1 \mathrm{AB}$ & $6.5 \mathrm{~A}$ & 5.0BCDE \\
\hline & F. brev. & Mentor & $2.0 \mathrm{ABC}$ & $1.0 \mathrm{E}$ & 2.6ABCD & $4.5 \mathrm{AB}$ & $7.1 \mathrm{~A}$ & 5.8ABCDE \\
\hline & F. rubrac. & Musica & $1.3 \mathrm{BC}$ & $1.5 \mathrm{E}$ & 2.5ABCDE & $4.8 \mathrm{AB}$ & $6.0 \mathrm{~A}$ & $6.4 \mathrm{ABC}$ \\
\hline & F. rubra l. & Samanta & $1.0 \mathrm{C}$ & $1.3 \mathrm{E}$ & 1.6CDE & $4.4 \mathrm{AB}$ & $6.8 \mathrm{~A}$ & $6.5 \mathrm{AB}$ \\
\hline \multirow[t]{6}{*}{ Control } & F. rubrar. & Barisse & $1.3 \mathrm{BC}$ & $1.3 \mathrm{E}$ & 2.5ABCDE & $4.8 \mathrm{AB}$ & $6.9 \mathrm{~A}$ & 5.9ABCDE \\
\hline & F. rubra l. & Barpearl & $1.0 \mathrm{C}$ & $1.6 \mathrm{E}$ & 2.1ABCDE & 4.6AB & $6.5 \mathrm{~A}$ & $6.8 \mathrm{~A}$ \\
\hline & Schedon. a. & Melyane & $1.8 \mathrm{ABC}$ & 3.0ABCD & $2.8 \mathrm{ABCD}$ & $4.0 \mathrm{AB}$ & $6.4 \mathrm{~A}$ & 4.9CDE \\
\hline & F. brev. & Mentor & $2.5 \mathrm{AB}$ & $1.3 \mathrm{E}$ & $3.0 \mathrm{ABC}$ & $4.0 \mathrm{AB}$ & $6.9 \mathrm{~A}$ & 5.6ABCDE \\
\hline & F. rubrac. & Musica & $1.0 \mathrm{C}$ & 1.9CDE & 2.1ABCDE & $4.9 \mathrm{AB}$ & $6.8 \mathrm{~A}$ & $6.9 \mathrm{~A}$ \\
\hline & F. rubra l. & Samanta & $1.0 \mathrm{C}$ & $1.3 \mathrm{E}$ & $1.0 \mathrm{E}$ & $4.6 \mathrm{AB}$ & $6.6 \mathrm{~A}$ & $6.4 \mathrm{ABC}$ \\
\hline
\end{tabular}

* Values in each column (i.e., separately for each year and DAS) followed by the same letter are not significantly different according to simulated adjustment (0.05). 


\subsection{Weed Cover}

There were no differences in weed cover on 14 DAS in 2018. The lowest weed cover in 2019 was recorded on control plots seeded with Mentor, and there were no differences among any other grass $\times$ weed combinations (Table 4). On 54 and 84 DAS, grass control plots generally exhibited the lowest weed coverage (Table 4) and weed control plots had the highest percent weed cover. However, coverage did not separate clearly and consistently among the different grass by weed combinations (Table 4). In 2018, 84 DAS, plots sown with the cultivar Samanta placed in the group with the highest weed cover regardless of weed treatment, however no clear trends emerged because of significant overlap with other grasses (Table 4). Aside from weed cover on control plots, weed cover in 2019 was greatest on Melyane plots, but again no clear trend emerged among the other treatments. Figure 1 shows images of Mentor (Festuca. brevipila) with no weed cover, of Musica (F. rubra commutata) with $22 \%$ weed cover, and of a clover control plot with $62 \%$ weed cover.

\begin{tabular}{|c|c|c|c|c|c|}
\hline $\begin{array}{c}\text { Grass }+ \\
\text { Weed }\end{array}$ & Lightbox Image & $\begin{array}{c}\text { Lightbox Image with point } \\
\text { quadrat frame }\end{array}$ & $\begin{array}{c}\text { Visual } \\
\text { score }\end{array}$ & $\begin{array}{c}\text { Weed } \\
\text { cover }\end{array}$ & $\begin{array}{c}\text { Turf } \\
\text { Analyzer }\end{array}$ \\
\hline $\begin{array}{c}\text { Musica } \\
\text { with no } \\
\text { weed } \\
\text { (Control) }\end{array}$ & & 7 & $2 \%$ & $78.6 \%$ \\
\hline Mentor \\
Clover
\end{tabular}

Figure 1. Visual score, percent weed cover and percent turf cover determined by Turf Analyzer of Festuca. brevipila cultivar Mentor with no weed (top row), of Festuca rubra commutata cultivar Mentor seeded with clover (middle row) and of a clover control plot with no grass (bottom row).

\subsection{Visual Quality}

Generally, visual quality of plots seeded with grasses and weeds was higher in 2019 compared to 2018. In 2019, ten grass $\times$ weed treatment combinations exhibited a visual quality of six or higher, whereas in 2018 only Musica in combination with the weed mixture reached 6.0 (Table 5). As expected, control plots (plots sown with grasses only) were among the plots with the highest average visual scores, except for Melyane in 2019. They all rated 6.0 or higher, which is considered an acceptable level of turfgrass quality. Only Mentor and Melyane reached 6.5 in 2018 and Barpearl, Musica, and Samanta without weeds rated 6.8 in 2019 (Table 6). However, visual quality of the grass-only plots did not exceed quality ratings of plots seeded with grasses plus weeds, and there was no clear trend indicating that grasses alone exhibited greater quality than grasses in combination with weeds. 
Table 5. Percent weed cover (estimated means) of fine (Festuca L. spp.) and tall fescue (Schedonorus arundinaceus (Schreb.) Dumort.) cultivars and in control plots (no grass) sown in 2018 and 2019 on 26, 54, 84 days after seeding fescue grasses (DAS). Fescue grasses were seeded with either white clover (Trifolium repens L.), daisy (Bellis perennis L.), yarrow (Achillea millefolium L.), a mixture of all three weed species or without weeds (Control). Treatments also included weed only (Control II) plots.

\begin{tabular}{|c|c|c|c|c|c|c|c|c|}
\hline \multirow{2}{*}{ Weed } & \multirow{2}{*}{ Species } & \multirow{2}{*}{ Cultivar } & \multicolumn{2}{|c|}{ DAS 26} & \multicolumn{2}{|c|}{ DAS 54} & \multicolumn{2}{|c|}{ DAS 84} \\
\hline & & & 2018 & 2019 & 2018 & 2019 & 2018 & 2019 \\
\hline \multirow[t]{7}{*}{ Clover } & F. rubra r. & Barisse & $8.0 \mathrm{~A} *$ & 7.9AB & 15.6DEFGH & 15.6ABCD & 40.1ABCDE & 20.8ABCDE \\
\hline & F. rubral. & Barpearl & $3.5 \mathrm{~A}$ & $7.4 \mathrm{AB}$ & 15.6DEFGH & 14.5ABCD & 31.9CDEF & 21.2ABCDE \\
\hline & Schedon. $a$. & Melyane & $5.9 \mathrm{~A}$ & $17.1 \mathrm{~A}$ & 17.0DEFGH & 26.7AB & 38.4ABCDE & 32.7ABCD \\
\hline & F. brev. & Mentor & $5.3 \mathrm{~A}$ & $3.6 \mathrm{AB}$ & 9.6FGHIJ & 17.1ABCD & 26.7DEFG & 21.7ABCDE \\
\hline & F. rubrac. & Musica & $3.9 \mathrm{~A}$ & 8.0AB & 16.4DEFGH & 14.0ABCD & 28.4DEFG & 18.0ABCDE \\
\hline & F. rubra l. & Samanta & $5.5 \mathrm{~A}$ & $3.9 \mathrm{AB}$ & 22.2BCDEFG & 15.4ABCD & 53.3ABCD & 23.6ABCDE \\
\hline & Control II & & $6.5 \mathrm{~A}$ & $5.8 \mathrm{AB}$ & 35.7ABCD & 17.5ABCD & 71.3ABC & 25.8ABCDE \\
\hline \multirow[t]{7}{*}{ Daisy } & F. rubrar. & Barisse & $4.6 \mathrm{~A}$ & $6.6 \mathrm{AB}$ & 10.4EFGHIJ & 18.6ABCD & 21.5EFG & 26.5ABCDE \\
\hline & F. rubral. & Barpearl & $7.4 \mathrm{~A}$ & $11.5 \mathrm{AB}$ & 16.6DEFGH & 16.4ABCD & 40.4ABCDE & 20.8ABCDE \\
\hline & Schedon. $a$. & Melyane & $4.5 \mathrm{~A}$ & 16.7A & 19.9CDEFG & $28.0 \mathrm{AB}$ & 40.9ABCDE & $37.0 \mathrm{AB}$ \\
\hline & F. brev. & Mentor & $3.0 \mathrm{~A}$ & 11.7AB & 15.1DEFGH & $23.8 \mathrm{ABC}$ & 27.0DEFG & 32.5ABCDE \\
\hline & F. rubrac. & Musica & $6.4 \mathrm{~A}$ & $12.8 \mathrm{AB}$ & 23.8BCDEF & 18.7ABCD & 41.7ABCDE & 22.7ABCDE \\
\hline & F. rubra l. & Samanta & $8.4 \mathrm{~A}$ & $15.1 \mathrm{~A}$ & 31.2ABCDEF & 18.7ABCD & 50.7ABCDE & 22.4ABCDE \\
\hline & Control II & & $3.2 \mathrm{~A}$ & $9.1 \mathrm{AB}$ & 36.6ABCD & $29.4 \mathrm{~A}$ & 79.3AB & $38.6 \mathrm{~A}$ \\
\hline \multirow[t]{7}{*}{ Yarrow } & F. rubrar. & Barisse & $6.2 \mathrm{~A}$ & $14.0 \mathrm{~A}$ & 31.9ABCDE & 18.7ABCD & 44.5ABCDE & 26.1ABCDE \\
\hline & F. rubra l. & Barpearl & $7.4 \mathrm{~A}$ & $10.7 \mathrm{AB}$ & 41.1ABCD & 12.4ABCD & 56.4ABCD & 15.1BCDE \\
\hline & Schedon. a. & Melyane & $9.6 \mathrm{~A}$ & $12.9 \mathrm{AB}$ & 26.3BCDEF & $20.9 \mathrm{ABC}$ & $34.7 \mathrm{CDE}$ & 24.8ABCDE \\
\hline & F. brev. & Mentor & $8.5 \mathrm{~A}$ & $8.5 \mathrm{AB}$ & $34.2 \mathrm{ABCD}$ & $9.4 \mathrm{ABCD}$ & 51.6ABCD & 17.3ABCDE \\
\hline & F. rubra c. & Musica & $9.4 \mathrm{~A}$ & $15.5 \mathrm{~A}$ & 34.9ABCD & 17.7ABCD & 45.7ABCDE & 23.1ABCDE \\
\hline & F. rubra l. & Samanta & $9.6 \mathrm{~A}$ & $14.1 \mathrm{~A}$ & $50.3 \mathrm{ABC}$ & 14.9ABCD & 56.7ABCD & 19.6ABCDE \\
\hline & Control II & & $12 \mathrm{~A}$ & $17.8 \mathrm{~A}$ & 76.1A & $28.6 \mathrm{AB}$ & $82.6 \mathrm{~A}$ & $35.6 \mathrm{ABC}$ \\
\hline \multirow[t]{7}{*}{ Mixture } & F. rubrar. & Barisse & $5.4 \mathrm{~A}$ & 8.3AB & 18.5CDEFG & 11.5ABCD & 37.7ABCDE & 19.6ABCDE \\
\hline & F. rubra l. & Barpearl & $6.0 \mathrm{~A}$ & $11.9 \mathrm{AB}$ & 31.1ABCDEF & 16.2ABCD & 49.0ABCDE & 25.8ABCDE \\
\hline & Schedon. a. & Melyane & $3.4 \mathrm{~A}$ & 17.1A & 13.5DEFGHI & $23.2 \mathrm{ABC}$ & 34.4CDE & 30.1ABCDE \\
\hline & F. brev. & Mentor & $4.7 \mathrm{~A}$ & $14.9 \mathrm{~A}$ & 21.3CDEFG & $20.9 \mathrm{ABC}$ & 36.1BCDE & 23.3ABCDE \\
\hline & F. rubrac. & Musica & $7.1 \mathrm{~A}$ & $10.4 \mathrm{AB}$ & 19.7CDEFG & 13.9ABCD & 27.2DEFG & 21.0ABCDE \\
\hline & F. rubra l. & Samanta & $4.5 \mathrm{~A}$ & $13.9 \mathrm{~A}$ & 33.8ABCD & $19 A B C D$ & 48.9ABCDE & 25.3ABCDE \\
\hline & Control II & & $5.6 \mathrm{~A}$ & $12.5 \mathrm{AB}$ & $61.9 \mathrm{AB}$ & $22.3 \mathrm{ABC}$ & $78.4 \mathrm{AB}$ & 32.7ABCD \\
\hline \multirow[t]{6}{*}{ Control } & F. rubrar. & Barisse & $0.2 \mathrm{~A}$ & $5.2 \mathrm{AB}$ & $1.5 \mathrm{~J}$ & 8.5BCD & $2.8 \mathrm{H}$ & 12.7DE \\
\hline & F. rubra l. & Barpearl & $1.0 \mathrm{~A}$ & $3.6 \mathrm{AB}$ & 6.3GHIJ & $10.2 \mathrm{ABCD}$ & 12.1FGH & 16.1ABCDE \\
\hline & Schedon. a. & Melyane & $0.5 \mathrm{~A}$ & $7.2 \mathrm{AB}$ & $2.0 \mathrm{~J}$ & 10.3ABCD & $4.3 \mathrm{H}$ & 15.5ABCDE \\
\hline & F. brev. & Mentor & $0.5 \mathrm{~A}$ & $0.5 \mathrm{~B}$ & 2.7IJ & $4.7 \mathrm{D}$ & $10.4 \mathrm{GH}$ & $12.2 \mathrm{E}$ \\
\hline & F. rubra c. & Musica & $0.2 \mathrm{~A}$ & $4.4 \mathrm{AB}$ & $2.2 \mathrm{~J}$ & 7.0CD & $5.5 \mathrm{H}$ & 13.7CDE \\
\hline & F. rubra l. & Samanta & $0.5 \mathrm{~A}$ & $5.0 \mathrm{AB}$ & $4.0 \mathrm{HIJ}$ & 9.2ABCD & $10.4 \mathrm{GH}$ & 13.1DE \\
\hline
\end{tabular}

* Values in each column (i.e., separately for each year and DAS) followed by the same letter are not significantly different according to simulated adjustment (0.05). 
Table 6. Visual quality of fine (Festuca L. spp.) and tall fescue (Schedonorus arundinaceus (Schreb.) Dumort.) cultivars and in control plots (no grass) sown in 2018 and 201984 days after seeding (DAS). Fescue grasses were seeded with either white clover (Trifolium repens L.), daisy (Bellis perennis L.), yarrow (Achillea millefolium L.), a mixture of all three weed species or without weeds (Control). Treatments also included weed only (Control II) plots.

\begin{tabular}{|c|c|c|c|c|}
\hline \multirow{2}{*}{ Weed } & \multirow{2}{*}{ Species } & \multirow{2}{*}{ Cultivar } & \multicolumn{2}{|c|}{ Quality } \\
\hline & & & 2018 & 2019 \\
\hline \multirow[t]{7}{*}{ Clover } & F. rubrar. & Barisse & $4.2 \mathrm{BCDE}^{*}$ & $5.3 \mathrm{ABC}$ \\
\hline & F. rubral. & Barpearl & 5.7ABC & $6.0 \mathrm{AB}$ \\
\hline & Schedon. a. & Melyane & 4.2BCDE & $3.0 \mathrm{DE}$ \\
\hline & F. brev. & Mentor & 4.5ABCDE & 4.5BCD \\
\hline & F. rubrac. & Musica & 4.7ABCD & $6.3 \mathrm{AB}$ \\
\hline & F. rubra l. & Samanta & 4.2BCDE & $5.5 \mathrm{AB}$ \\
\hline & Control II & & $1.5 \mathrm{~F}$ & $1.0 \mathrm{E}$ \\
\hline \multirow[t]{7}{*}{ Daisy } & F. rubrar. & Barisse & 5.2ABCD & $5.5 \mathrm{AB}$ \\
\hline & F. rubral. & Barpearl & 5.0ABCD & 5.3ABC \\
\hline & Schedon. a. & Melyane & 3.2DEF & 3.3CD \\
\hline & F. brev. & Mentor & 5.2ABCD & 4.8ABCD \\
\hline & F. rubrac. & Musica & 5.0ABCD & $6.3 \mathrm{AB}$ \\
\hline & F. rubral. & Samanta & 4.5ABCDE & 5.0ABCD \\
\hline & Control II & & $1.2 \mathrm{~F}$ & $1.0 \mathrm{E}$ \\
\hline \multirow[t]{7}{*}{ Yarrow } & F. rubral. & Barpearl & 4.7ABCD & $6.8 \mathrm{~A}$ \\
\hline & F. rubrar. & Barisse & 5.2ABCD & $6.3 \mathrm{AB}$ \\
\hline & Schedon. a. & Melyane & 4.7ABCD & 3.0DE \\
\hline & F. brev. & Mentor & 4.5ABCDE & 5.3ABC \\
\hline & F. rubrac. & Musica & 4.5ABCDE & $6.3 \mathrm{AB}$ \\
\hline & F. rubral. & Samanta & 4.0CDE & $6.7 \mathrm{~A}$ \\
\hline & Control II & & $2.5 \mathrm{EF}$ & $1.0 \mathrm{E}$ \\
\hline \multirow[t]{7}{*}{ Mixture } & F. rubral. & Barpearl & 5.0ABCD & $6.5 \mathrm{AB}$ \\
\hline & F.rubrar. & Barisse & 5.0ABCD & $5.8 \mathrm{AB}$ \\
\hline & Schedon. a. & Melyane & 5.0ABCD & 3.3CD \\
\hline & F. brev. & Mentor & 5.2ABCD & 5.3ABC \\
\hline & F. rubrac. & Musica & 6.0ABC & $6.5 \mathrm{AB}$ \\
\hline & F. rubral. & Samanta & 4.7ABCD & $6.0 \mathrm{AB}$ \\
\hline & Control II & & $1.2 \mathrm{~F}$ & $1.0 \mathrm{E}$ \\
\hline \multirow[t]{6}{*}{ Control } & F. rubral. & Barpearl & $6.2 \mathrm{AB}$ & $6.8 \mathrm{~A}$ \\
\hline & F. rubrar. & Barisse & $6.2 \mathrm{AB}$ & $6.0 \mathrm{AB}$ \\
\hline & Schedon. a. & Melyane & 6.0ABC & 3.3CD \\
\hline & F. brev. & Mentor & $6.5 \mathrm{~A}$ & $6.0 \mathrm{AB}$ \\
\hline & F. rubrac. & Musica & $6.5 \mathrm{~A}$ & $6.8 \mathrm{~A}$ \\
\hline & F. rubral. & Samanta & 6.0ABC & $6.8 \mathrm{~A}$ \\
\hline
\end{tabular}

* Values in each column (separately for each year) followed by the same letter are not significantly different according to simulated adjustment (0.05).

\subsection{Vegetation Cover}

Vegetation cover data were only used for correlation analyses and are not presented or discussed in detail. Vegetation cover at 84 DAS was generally higher in 2018, ranging from $65 \%$ to $97 \%$ compared to $20 \%$ to $90 \%$ in 2019 (Figure 1).

\subsection{Correlations}

All measured parameters were significantly correlated with one another, except for grass vigor with weed cover and visual quality in 2018. When data for both years were compared, the correlation coefficient was highest between turfgrass vigor and vegetation cover (0.76) and lowest between turfgrass vigor and weed cover (0.21) (data not shown). Turfgrass vigor contributed strongly to vegetation cover $(r=0.76)$ but only moderately to visual quality $(r=0.36)$. An increase in weed cover resulted in a lower visual score, as indicated by the negative association $(-0.48)$. 
When correlations were examined separately for each year, visual quality was moderately negatively correlated with weed cover in both years, reaching -0.48 in 2018 , and -0.51 in 2019 (Figure 2). Grass vigor was strongly positively correlated with vegetation cover in 2019 (0.79) but only weakly in 2018 (0.32). The relationship between visual quality and vegetation cover showed a moderate positive correlation in 2019 (0.66) and a weak negative correlation $(-0.26)$ in 2018. A significant correlation between grass vigor and weed cover (-0.41) and grass vigor and visual quality (0.79) was only observed in 2019 (Figure 2).

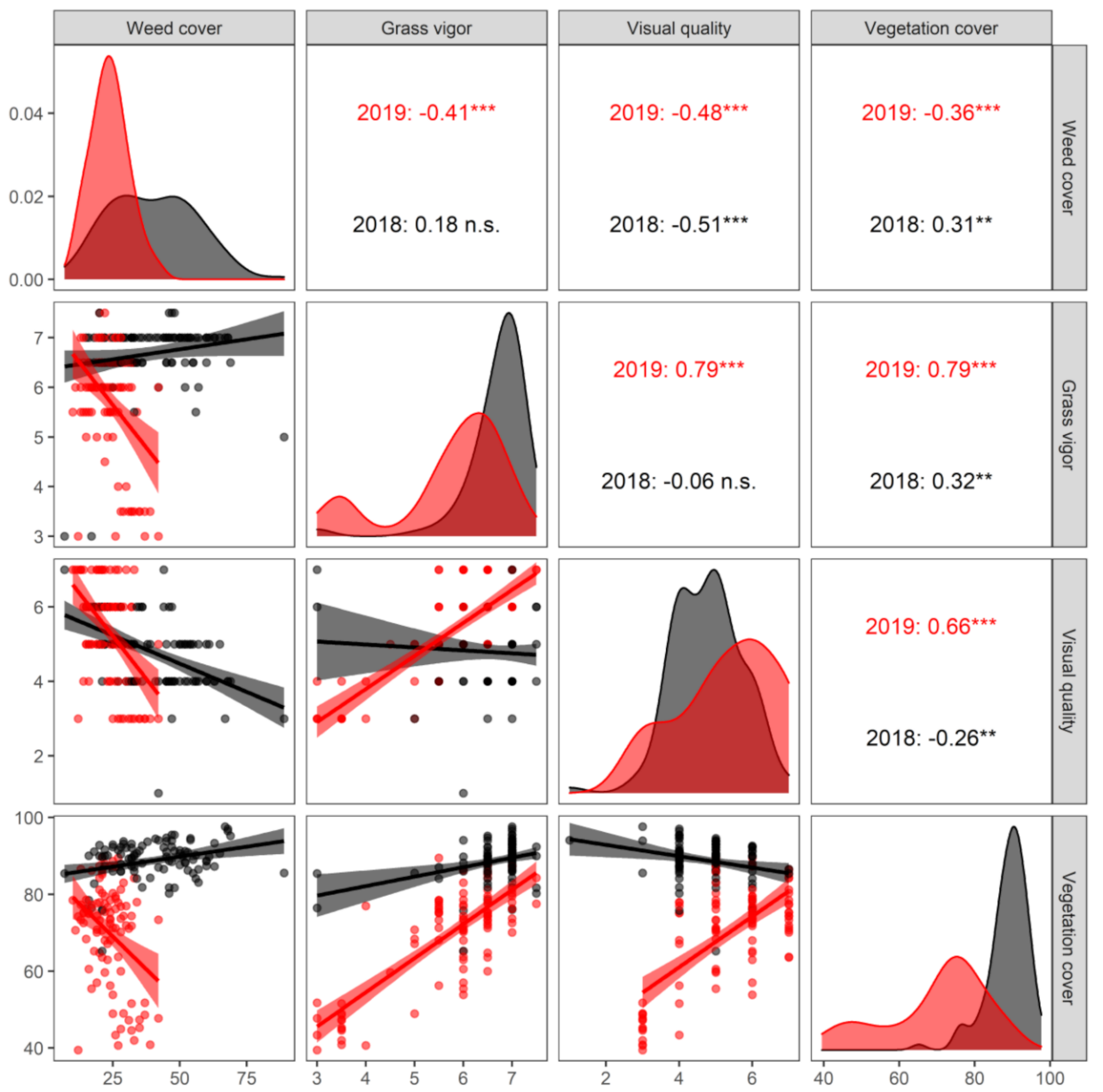

Figure 2. Pearson's coefficients of determination (r) (top right) between weed cover (measured by a 100-point quadrant, from 1-100\%), grass vigor (visual score, from 0-9), visual quality (visual score, from 1-9), and vegetation cover (measured by digital image analysis using TurfAnalyzer software, from 1-100\%). in 2018 (black) and 2019 (red), data were collected 84 days after seeding on plots sown with one of six grasses, one of four weed treatments and replicated four times. Line charts (bottom left) indicate linear regression line and data distribution between output variables. Graphs (diagonal) depict data density of variables. ${ }^{* *}{ }^{* * *}$ Significant at the 0.01 , and 0.001 probability level, respectively. n.s. Not significant at the 0.05 probability level.

\section{Discussion}

The prime objective of the present study was to assess the capacity of fine and tall fescues to interfere with the growth of several common turf weeds. The percent of weed cover was generally higher in 2018 than in 2019, which could be attributed to higher overall temperatures in 2018. Maximum daily temperatures were higher in $2018\left(25.3^{\circ} \mathrm{C}\right)$ compared to $2019\left(18.4^{\circ} \mathrm{C}\right)$, most likely contributing to the more vigorous weed growth observed in 2018. Optimal temperatures for clover seed germination have been determined to range between $10.9^{\circ} \mathrm{C}$ and $17.2^{\circ} \mathrm{C}$ [39]. This might explain the difference in weed cover 
between the two years, as average daily temperatures were within this optimal range on 74 days in 2018 compared to only 57 days in 2019 . Maximum germination rates (82\%) for yarrow under frequent irrigation rates have been reported between $22{ }^{\circ} \mathrm{C}$ to $29^{\circ} \mathrm{C}$ [ 40 ], and $25^{\circ} \mathrm{C}$ was reported to be an optimal temperature for germination of daisy [41]. Therefore, and regardless of weed treatment, germination of weed seed was favored in 2018 due to higher average temperatures, resulting in greater weed cover. However, it was not possible to determine if any of the weed species tested were more or less susceptible to growth interference by fine or tall fescues.

Fescue cultivars did not differ in their ability to interfere with growth of weeds during establishment. Results in this study do not support the few existing studies that suggest that both Chewings fescue (=Musica) and strong creeping red fescue (=Barisse) naturally interfere with growth of mature broadleaf weed species $[10,15,17]$ in part because both species produce detectable amounts of the allelopathic non-protein amino acid m-tyrosine, which contributes to growth interference of other receiver plants [21].

To examine potential drivers of growth interference, vigor data were collected, based on the assumption that a more rapidly developing sward is likely to outcompete neighboring weed species [6]. Shortly after germination (14 DAS), differences in vigor between cultivars and year were minor, except for the tall fescue cultivar Melyane, which showed higher vigor (greater than three) compared to other cultivars (vigor scores of two or lower for most cultivar $\times$ weed combinations) in 2019. However, the competitive advantages conferred by early vigor in Melyane were short lived, with several cultivar $\times$ weed combinations reaching similar vigor at 39 DAS in both years. Some authors have reported that Chewings- and strong creeping red fescue develop vigor more rapidly than hard fescue during establishment $[10,17]$, which could not be confirmed based on the data. On the final day of the experiment in 2018, all cultivars established with the same degree of vigor, whereas in 2019 we observed treatment differences and Barpearl and Musica placed in the group with the highest vigor scores for all weed treatments. Tall fescue varieties are known to lose turfgrass cover under low mowing regimes [24,42], which was observed in both years after mowing was initiated. Tall fescue varieties are used for athletic fields in European transition zones [19], however, results showed that Melyane is an unsuitable cultivar for natural weed suppression in turf mowed at $15 \mathrm{~mm}$ or less twice a week in cool-season climates such as the Netherlands. This conclusion was based on visual quality data, not on weed cover data.

Even though visual quality in 2018 did not vary among cultivars within the different weeds, Melyane performed poorly in 2019, with scores never exceeding 3.3. Most other cultivars scored greater than six in 2019, with Barpearl and Musica consistently scoring above six in all weeds. Nonetheless, upon examination of visual scores of fescues subjected to different weed treatments, it was unclear if any weed treatment resulted in particularly good or bad scores, as all weed control plots scored lower than the cultivar $\times$ weed plots.

In general, annual differences observed between data collected from both years of this study can be attributed to different weather conditions. In 2018, 19 days out of 84 reached a maximum temperature of greater than $30^{\circ} \mathrm{C}$, whereas the next year only seven days of the experimental period reached temperatures above $30^{\circ} \mathrm{C}$. Even though maximum daily temperatures exceeding $30{ }^{\circ} \mathrm{C}$ were first recorded late into both years of the study (day 59 in 2018 and day 79 in 2019), the higher mean temperatures in 2018 probably promoted better grass establishment and consequently higher grass vigor. In 2018, irrigating regularly was necessary because of low precipitation rates in November, whereas in 2019 irrigation was only required in the first two weeks, as precipitation was sufficient to ensure good establishment.

Annual differences were also reflected in the correlation analysis. Across both years, data showed that visual quality decreased with an increase in weed cover. This was expected, as weed cover is a factor that influences visual quality [33]. Also grass vigor was significantly correlated with vegetation cover, strongly in 2019 and to a lesser degree in 2018. Vegetation cover describes the surface area covered by all green vegetation, with no 
distinction between weeds and grasses. The stronger association between vigor and cover in 2019 is the result of greater differences in the extent of establishment among grasses, reflected by data points distributed over a wider range of cover, from low to high. In 2018, all grasses established equally well, and data points were concentrated at the high cover area (Figure 1).

Visual quality was positively and significantly associated with vegetation cover and grass vigor in 2019, but not in 2018. Similar to the observed association between grass vigor and vegetation cover, differences in vigor among varieties were greater in 2019 because grasses established differently, which resulted in a wider spread of data points and a stronger association. In this study, a more vigorous growing turf resulted in less weeds. However, the experimental set-up was not designed to examine the underlying mechanisms of growth interference in detail.

\section{Conclusions}

Differences in mean temperatures and precipitation between the two years of the study resulted in differences in growth of grasses and weeds, as well as in the extent of weed interference of Festuca cultivars. Nonetheless, cultivars Musica (Chewings fescue) and Barpearl (slender creeping red fescue) were the least affected by weed growth during both years, resulting in acceptable aesthetic quality of these turf stands after establishment. Both grasses appear to be interesting candidates for further investigations into the mechanisms responsible for growth interference of broadleaf weeds. The three weed species selected for this study were all similarly affected by the grasses used in the study. Tall fescue Melyane appeared to be an unsuitable turfgrass for areas destined for maintenance without herbicides because of the low visual quality and aesthetic appearance after mowing at a height of $15 \mathrm{~mm}$ or less.

Further research needs to be conducted to better understand the mechanisms of growth interference. Plant and root morphology, as well as allelopathic exudates are all traits that contribute to competition mechanisms, but extent and efficacy of these mechanisms not just in establishing but also in mature turf needs further investigation.

Author Contributions: Conceptualization, D.H. and B.L.; methodology, D.H., C.V.-C. and B.L.; validation, D.H., C.V.-C., A.M. and B.L.; formal analysis, D.H., C.V.-C. and A.M.; investigation, D.H.; resources, D.H.; data curation, D.H. and A.M.; writing-original draft preparation, D.H. and B.L.; writing—review and editing, D.H., B.L., C.V.-C., B.L. and A.M.; visualization, D.H. and A.M.; supervision, B.L.; project administration, B.L.; funding acquisition, B.L. All authors have read and agreed to the published version of the manuscript.

Funding: Financial support of this project was provided by the Turfgrass University Research Foundation (TuRF), Nederlandse Golf Federatie (NGF), Nederlandse Vereniging van Golfaccommodaties (NVG), and Nederlandse Greenkeepers Associatie (NGA).

Data Availability Statement: All data in possession of first author. No public storage of data.

Acknowledgments: We are grateful for the contribution of Barenbrug Holland B.V. in Nijmegen, The Netherlands. Rossana Sallenave's help with the manuscript is also greatly appreciated.

Conflicts of Interest: The authors declare no conflict of interest.

\section{References}

1. Kristoffersen, P.; Rask, A.M.; Grundy, A.C.; Franzen, I.; Kempenaar, C.; Raisio, J.; Schroeder, H.; Spijker, J.; Verschwele, A.; Zarina, L. A review of pesticide policies and regulations for urban amenity areas in seven European countries. Weed Res. 2008, 48, 201-214. [CrossRef]

2. Malaguerra, F.; Albrechtsen, H.J.; Thorling, L.; Binning, P.J. Pesticides in water supply wells in Zealand, Denmark: A statistical analysis. Sci. Total Environ. 2012, 414, 433-444. [CrossRef] [PubMed]

3. Mansveld, W.J.; Kamp, H.G.J.; Bolhuis, J.H.; Zelsman, W.P.; Van Hoesen, J.; Vernooij, M.J.; de Jeu, A.; Moonen, L.G.W.; Roozen, E.M.A.M.; Zweverink, H. C-189 Green Deal Gebruik van Gewasbeschermingsmiddelen op Sportvelden. Available online: https://www.greendeals.nl/green-deals/gebruik-van-gewasbeschermingsmiddelen-op-sportvelden (accessed on 3 March 2018). 
4. Meftaul, I.M.; Venkateswarlu, K.; Dharmarajan, R.; Annamalai, P.; Megharaj, M. Pesticides in the urban environment: A potential threat that knocks at the door. Sci. Total Environ. 2020, 711, 1-15. [CrossRef] [PubMed]

5. Raikes, C.; Lepp, N.W.; Canaway, P.M. Major diseases, pests and weeds of winter sports turf. II. A questionnaire survey of local authorities. J. Sport Turf Res. Inst. 1994, 70, 83-99.

6. Busey, P. Cultural Management of Weeds in Turfgrass: A Review. Crop Sci. 2003, 43, 1899-1911. [CrossRef]

7. Larsen, S.U.; Kristoffersen, P.; Fischer, J. Turfgrass management and weed control without pesticides on football pitches in Denmark. Pest Manag. Sci. 2004, 60, 579-587. [CrossRef] [PubMed]

8. Masin, R.; Zuin, M.C.; Archer, D.W.; Forcella, F.; Zanin, G. WeedTurf: A predictive model to aid control of annual summer weeds in turf. Weed Sci. 2005, 53, 193-201. [CrossRef]

9. Pirchio, M.; Fontanelli, M.; Frasconi, C.; Martelloni, L.; Raffaelli, M.; Peruzzi, A.; Gaetani, M.; Magni, S.; Caturegli, L.; Volterrani, M.; et al. Autonomous Mower vs. Rotary Mower: Effects on turf quality and weed control in tall fescue lawn. Agronomy 2018, 8, 15. [CrossRef]

10. Braun, R.C.; Patton, A.J.; Watkins, E.; Koch, P.L.; Anderson, N.P.; Bonos, S.A.; Brilman, L.A. Fine fescues: A review of the species, their improvement, production, establishment, and management. Crop Sci. 2020, 60, 1142-1187. [CrossRef]

11. Hahn, D.; Sallenave, R.; Pornaro, C.; Leinauer, B. Managing cool-season turfgrass without herbicides: Optimizing maintenance practices to control weeds. Crop Sci. 2020, 60, 2204-2220. [CrossRef]

12. Grimshaw, A.L.; Qu, Y.; Meyer, W.A.; Watkins, E.; Bonos, S.A. Heritability of simulated wear and traffic tolerance in three fine fescue species. HortScience 2018, 53, 416-420. [CrossRef]

13. Ruemmele, B.A.; Brilman, L.A.; Huff, D.R. Fine Fescue Germplasm Diversity and Vulnerability. Crop Sci. 1995, 35, 313. [CrossRef]

14. Stace, A. The distinction between the Festuca ovina L. and Festuca rubra L. aggregates in the British Isles. Watsonia 1992, 19, 107-112.

15. Horgan, B.; Hollman, A.; Koeritz, E.; Stier, J. Golf Course Management; GCSAA: Lawrence, KS, USA, 2007; pp. 112-120.

16. Lane, I.; Watkins, E.; Spivak, M. Turfgrass species affect the establishment and bloom of kura clover (Trifolium ambiguum) in lawns. HortScience 2019, 54, 824-828. [CrossRef]

17. Bertin, C.; Senesac, A.F.; Rossi, F.S.; DiTommaso, A.; Weston, L.A. Evaluation of selected fine-leaf fescue cultivars for their turfgrass quality and weed suppressive ability in field settings. Horttechnology 2009, 19, 660-668. [CrossRef]

18. Sun, J.; Meyer, W.; Cross, J.; Huang, B. Growth and physiological traits of canopy and root systems associated with drought resistance in Tall fescue. Crop Sci. 2013, 53, 575-584. [CrossRef]

19. Pornaro, C.; Barolo, E.; Rimi, F.; Macolino, S.; Richardson, M. Performance of various cool-season turfgrasses as influenced by simulated traffic in northeastern Italy. Eur. J. Hortic. Sci. 2016, 81, 27-36. [CrossRef]

20. Bertin, C.; Paul, R.N.; Duke, S.O.; Weston, L.A. Laboratory assessment of the allelopathic effects of fine leaf fescues. J. Chem. Ecol. 2003, 29, 1919-1937. [CrossRef]

21. Bertin, C.; Weston, L.A.; Huang, T.; Jander, G.; Owens, T.; Meinwald, J.; Schroeder, F.C. Grass roots chemistry: Meta-Tyrosine, an herbicidal nonprotein amino acid. Proc. Natl. Acad. Sci. USA 2007, 104, 16964-16969. [CrossRef]

22. Luu, K.T.; Matches, A.G.; Peters, E.J. Allelopathic Effects of Tall Fescue on Birdsfoot Trefoil as Influenced by N Fertilization and Seasonal Changes. Agron. J. 1982, 74, 805-808. [CrossRef]

23. BSPB Turfgrass Seed 2017-The Buyers Guide to Quality Amenity Turfgrasses. Available online: https://www.manualzz.com (accessed on 18 October 2017).

24. Beard, J.B. Turfgrass Science and Culture, 1st ed.; Prentice-Hall: Hoboken, NJ, USA, 1973; ISBN 013933002X.

25. Lalljee, B.; Facknath, S. Allelopathic interactions in soil. In Allelopathy in Ecological Agriculture and Forestry; Springer: Berlin, Germany, 2000; pp. 47-58.

26. Beard, J.B. Turf Management for Golf Courses; Ann Arbor Press: Ann Arbor, MI, USA, 2002; ISBN 9781575040929.

27. Karcher, D.E.; Richardson, M.D. Digital image analysis in turfgrass research. Turfgrass Biol. Use Manag. 2013, 56, 1133-1149.

28. Karcher, D.E.; Richardson, M.D. Quantifying turfgrass color using digital image analysis. Crop Sci. 2003, 43, 943-951. [CrossRef]

29. Ikemura, Y. Using Digital Image Analysis to Measure the Nitrogen Concentration of Turfgrasses; Univ. of Arkansas: Fayetteville, AR, USA, 2003.

30. Turf Analyzer Analyze Plant Health. Available online: http:/ / turfanalyzer.com (accessed on 7 April 2019).

31. Krans, J.V.; Morris, K. Determining a Profile of Protocols and Standards used in the Visual Field Assessment of Turfgrasses: A Survey of National Turfgrass Evaluation Program-Sponsored University Scientists. Appl. Turfgrass Sci. 2007, 4, 1-6. [CrossRef]

32. Leinauer, B.; VanLeeuwen, D.M.; Serena, M.; Schiavon, M.; Sevostianova, E. Digital image analysis and spectral reflectance to determine turfgrass quality. Agron. J. 2014, 106, 1787-1794. [CrossRef]

33. Morris, K.N. A guide to NTEP Turfgrass Ratings. Available online: http:/ / www.ntep.org/reports/ratings.htm (accessed on 3 April 2018).

34. Hulke, B.S.; Watkins, E.; Wyse, D.; Ehlke, N. Winterhardiness and turf quality of accessions of perennial ryegrass (Lolium perenne L.) from public collections. Crop Sci. 2007, 47, 1596-1602. [CrossRef]

35. Donart, G.B.; Youngner, V.B.; McKell, C.M. The Biology and Utilization of Grasses. J. Range Manag. 1973, 26, 155. [CrossRef]

36. Hoyle, J.A.; Yelverton, F.H.; Gannon, T.W. Evaluating Multiple Rating Methods Utilized in Turfgrass Weed Science. Weed Technol. 2013, 27, 362-368. [CrossRef] 
37. Lentner, M.; Bishop, T. Experimental Design and Analysis, 2nd ed.; Valley Book Company: Blacksburg, VA, USA, 1993; ISBN 9780961625528.

38. Marini, R.P. Approaches to analyzing experiments with factorial arrangements of treatments plus other treatments. HortScience 2003, 38, 117-120. [CrossRef]

39. Baxter, L.L.; Grey, T.L.; Tucker, J.J.; Hancock, D.W. Optimizing Temperature Requirements for Clover Seed Germination. Agrosyst. Geosci. Environ. 2019, 2, 1-7. [CrossRef]

40. Robocker, W.C. Germination of Seeds of Common Yarrow (Achillea millefolium) and Its Herbicidal Control. Weed Sci. 1977, 25, 456-459. [CrossRef]

41. Pêgo, R.; Grossi, J.A.; Barbosa, J.G. Soaking curve and effect of temperature on the germination of daisy seeds. Hortic. Bras. 2012, 30, 312-316. [CrossRef]

42. Moore, R.W.; Christians, N.E. Tall Fescue Management Study; Iowa State University: Aimes, IA, USA, 1989. 